Original Research Article

\title{
Simulation based learning methodology in pharmacology: knowledge and perception among second year medical under-graduate students
}

\author{
Nicole Pereira' ${ }^{1}$, Padmaja Udaykumar ${ }^{1 *}$, Lulu Sherif ${ }^{2}$
}

\begin{abstract}
${ }^{1}$ Department of Pharmacology,
${ }^{2}$ Academic In-charge,

Simulation and Skills centre, Fr

Muller Medical College,

Mangalore, Karnataka, India
\end{abstract}

Received: 21 January 2019

Accepted: 29 January 2019

\section{*Correspondence to: \\ Dr. Padmaja Udaykumar, \\ Email: padmajaudaykumar@ \\ fathermuller.in}

Copyright: (C) the author(s), publisher and licensee Medip Academy. This is an openaccess article distributed under the terms of the Creative Commons Attribution NonCommercial License, which permits unrestricted noncommercial use, distribution, and reproduction in any medium, provided the original work is properly cited.

\begin{abstract}
Background: Simulation-based learning (SBL) enhances problem-solving, improves skills in health care professionals. Authors assessed its use in teaching and learning pharmacology among medical undergraduates exposed to METIman, human patient simulator.

Methods: Medical undergraduate students exposed to SBL for over a year (8 clinical pharmacology related scenarios) were asked to fill a validated questionnaire at the end of the academic year.

Results: Of 145 students who underwent SBL, the data of 84 were analysed. The overall satisfaction score with SBL was highly significant in 79 (94\%) with a score of 26-35. Participants opined that it increases the depth of experience (91.6\%), provides a no risk learning and immediate feedback opportunity (93.4\%), a good opportunity to come across rare scenarios (86.2\%), enhances decision making, communication, teamwork and skill development (92\%); opportunity of repeated learning and enhanced patient safety at hospitals $(89.28 \%)$, reduces the dependency on patients $(72.8 \%)$, good opportunity for crisis training $(88.0 \%)$ were other factors favouring the use of SBL. Preference for an increase in the number of classes allotted to simulation $(27.4 \%)$ and reducing the duration of class $(9.6 \%)$ were the major suggestions. It is an excellent method to teach and make it interesting to learn pharmacology $(80.0 \%)$ Total score varied between $23-35$ with a mean \pm SD of $35 \pm 30.64$. None had a score of $7-15$.

Conclusions: SBL is an effective teaching and learning methodology with adequate participant satisfaction. It can be of immense utility as a learning tool with better outcome in learning, retention and recall.
\end{abstract}

Keywords: Decision making, Human patient simulator, Pharmacology, Simulation-based learning, Skill development, Teamwork

\section{INTRODUCTION}

Simulation-Based Learning (SBL) is a technique that amplifies real-life experiences with guided ones which are often "immersive" and those duplicate aspects of realworld scenarios in a fully interactive method. It involves a process where the student revise previously discussed topic than "immerse" themselves in a simulation experience and undergo debriefing with their facilitator. This method of learning and teaching helps both undergraduate and postgraduate medical students to enhance knowledge, decision-making skills, interpersonal and communication skills and nurture a tactical attitude towards patients. ${ }^{1}$ It is also a tool for assessment of performance. $^{2}$

Simulation-based teaching substitutes real patient encounters with high fidelity simulators like METIman, LUCINA and Human Patient Simulator (HPS) hence, replicating real-time patient scenarios in a realistic and controlled environment. The student learns to practice without risk and therefore reducing the chances of medical 
errors. Medical students also learn teamwork and behavioural skills as the multidisciplinary activity is essential as a health care professional. SBL provides various opportunities for one to rehearse and learn multiple times without causing undue harm to patients. ${ }^{3}$ Once limited to learn, practice and attain perfection in lifesaving skills, now they are proving useful in teaching other specialities of the medical profession, including pre and para-clinical subjects. The advantage includes active involvement of the learner, less risk with real-time experience. Introduction of these simulators in pharmacology is a new addition in the medical curriculum and has proved to be helpful in knowledge enhancement and student satisfaction. ${ }^{4-7}$

Authors introduced Simulation-based teaching methodology to teach pharmacology to $2^{\text {nd }}$-year medics and conducted this survey to determine the students' perception, to understand the knowledge, utility and associated challenges of this methodology to teach pharmacology to undergraduates.

There is limited data about simulation-based education used in Pharmacology in India.

\section{METHODS}

A cross-sectional study was conducted by the department of pharmacology of a medical college during 26 July 201826 August 2018, after obtaining approval from the Institutional Ethics Committee. Written consent was taken from all the participants who were the undergraduate medics and were exposed to SBL for over a year $(8$ clinical pharmacology related scenarios).

Authors gave a validated questionnaire at the end of the simulation case scenarios and participants were requested to complete it. The Participants were asked to provide their responses as a free text response survey was recorded under the title "suggestions". All the questionnaires were anonymous and marked with a number.

Students' perception was evaluated using 5-point Likert scale that indicates degrees of satisfaction.

Authors used a high-fidelity mannequin, METIman (MMP1223) (CAE healthcare, Australia). Cumulative scores for quality in levels of perception, good (26-35), fair (16-25), and poor (7-15). 94\% of the students scored a "good" cumulative score and 6\% scored between 6- 25 which was "fair".

\section{Statistical analysis}

Convenience sampling technique was used for sampling. Data was captured on Microsoft-Excel worksheets (2007) and analysed after editing for completeness. Completed questionnaires were analysed and we excluded incomplete ones. Descriptive statistical method was used to interpret data using frequency and percentage for categorical variables like gender. Primary descriptive statistical analysis of 5-point Likert items was conducted by calculating frequency, mean and standard deviation. The percentage of satisfaction of students was calculated by combining frequency of levels of perception and knowledge for each item in the questionnaire. Responses were measured with the 5-point Likert type scale from very dissatisfied (01) to very satisfied (05). A p-value of $<0.05$ was considered as being statistically significant. Overall suggestions were open-ended, and specific themes were derived from the responses. Results were used to support the quantitative and qualitative responses.

\section{RESULTS}

Of 145 students who underwent SBL, questionnaire was distributed to 100 (absent $=45$ ), and the response rate was $68.96 \%$; as there were incompletely answered questionnaires $(n=16)$, authors have analysed the data of 84 students.

The overall satisfaction score with SBL measured using 5point Likert scale and was highly significant in $79(94 \%)$ with a score of 26-35. Seventy-seven (91.6\%) students opined that it increases the depth of experience of a student. Seventy-nine $(93.4 \%)$ opined that it provides no risk learning and immediate feedback opportunity; an excellent opportunity to come across rare scenarios $(n=72,86.2 \%)$, enhances decision making, communication, teamwork and skill development $(n=77,92 \%)$ were other opinions by the participants (Table 1).

There were Seventy-five $(89.28 \%)$ opined that simulation gave an opportunity of repeated learning and enhanced patient safety at hospitals; $61(72.8 \%)$ considered that SB training reduces the dependency on patients. Seventy-four $(88.0 \%)$ were of the opinion that simulation-based training is a good opportunity for crisis training (Table 1).

Sixty-seven (79.8\%) opined that undergraduates, postgraduates, nursing staff and health care professionals could make the most use of the simulation training while eight $(9.5 \%)$ and four $(4.8 \%)$ opined that it is useful only for undergraduates and postgraduates, respectively (Table 2).

Qualitative responses by the students on SBL were based on free test responses under the suggestion section. A preference for an increase in the number of classes allotted to simulation $(\mathrm{n}=0.23,27.4 \%)$ and reduce the duration of class $(n=08,9.6 \%)$ were the major suggestions. Sixtyseven $(80.0 \%)$ considered it is an excellent method to teach and make it interesting to learn pharmacology (Table 3).

Participant's responses on the deficiencies and the corrective measure are tabulated in Table 4.

Total score based on the responses varied between 23 and 35 , with a mean \pm SD of $35 \pm 30.64$. None of the participants had a score of 7-15 (Figure 1). 
Table 1: Participants response to questionnaire.

\begin{tabular}{|c|c|c|c|c|c|c|c|c|}
\hline \multirow[b]{2}{*}{ Questions } & \multicolumn{6}{|c|}{ Response $\mathrm{n}(\%)$} & \multirow[b]{2}{*}{ Mean \pm SD } & \multirow[b]{2}{*}{$\begin{array}{l}\text { Mean } \\
(\%)\end{array}$} \\
\hline & $\begin{array}{l}\text { Strongly } \\
\text { disagree }\end{array}$ & Disagree & Neutral & Agree & $\begin{array}{l}\text { Strongly } \\
\text { agree }\end{array}$ & Total & & \\
\hline $\begin{array}{l}\text { Increases the depth of } \\
\text { experience }\end{array}$ & - & - & $\begin{array}{l}4 \\
(4.8 \%)\end{array}$ & $\begin{array}{l}27 \\
(32.1 \%)\end{array}$ & $\begin{array}{l}53 \\
(63.1 \%)\end{array}$ & 84 & $4.58 \pm 0.59$ & 91.6 \\
\hline $\begin{array}{l}\text { No risk learning, immediate } \\
\text { feedback opportunity }\end{array}$ & - & - & $\begin{array}{l}02 \\
(2.4 \%)\end{array}$ & $\begin{array}{l}24 \\
(28.6 \%)\end{array}$ & $\begin{array}{l}58 \\
(69.0 \%)\end{array}$ & 84 & $4.67 \pm 0.52$ & 93.4 \\
\hline $\begin{array}{l}\text { Good opportunity for } \\
\text { familiarity with rare scenarios }\end{array}$ & - & $01(1.2 \%)$ & $\begin{array}{l}13 \\
(15.2 \%)\end{array}$ & $\begin{array}{l}29 \\
(34.5 \%)\end{array}$ & $\begin{array}{l}41 \\
(48.8 \%)\end{array}$ & 84 & $4.31 \pm 0.78$ & 86.2 \\
\hline $\begin{array}{l}\text { Enhances decision making, } \\
\text { communication, team work, } \\
\text { skill development }\end{array}$ & - & - & $\begin{array}{l}06 \\
(7.1 \%)\end{array}$ & $\begin{array}{l}22 \\
(26.2 \%)\end{array}$ & $\begin{array}{l}56 \\
(66.7 \%)\end{array}$ & 84 & $4.60 \pm 0.62$ & 92.0 \\
\hline $\begin{array}{l}\text { An opportunity of repeated } \\
\text { learning and enhances patient } \\
\text { safety }\end{array}$ & - & $01(1.2 \%)$ & $\begin{array}{l}04 \\
(4.8 \%)\end{array}$ & $\begin{array}{l}36 \\
(42.9 \%)\end{array}$ & $\begin{array}{l}43 \\
(51.2 \%)\end{array}$ & 84 & $4.44 \pm 0.65$ & 88.8 \\
\hline $\begin{array}{l}\text { Reduces the dependency on } \\
\text { patients }\end{array}$ & $01(1.2 \%)$ & $\begin{array}{l}09 \\
(10.7 \%)\end{array}$ & $\begin{array}{l}24 \\
(28.6 \%)\end{array}$ & $\begin{array}{l}35 \\
(41.7 \%)\end{array}$ & $\begin{array}{l}15 \\
(17.9 \%)\end{array}$ & 84 & $3.64 \pm 0.94$ & 72.8 \\
\hline $\begin{array}{l}\text { Good opportunity for crisis } \\
\text { training }\end{array}$ & - & - & $\begin{array}{l}09 \\
(10.7 \%)\end{array}$ & $\begin{array}{l}32 \\
(38.1 \%)\end{array}$ & $\begin{array}{l}43 \\
(51.2 \%)\end{array}$ & 84 & $4.4 \pm 0.68$ & 88.0 \\
\hline
\end{tabular}

Table 2: Who would make the best use of the simulation and skills centre.

\begin{tabular}{|lll|}
\hline Category of healthcare professionals & $\mathbf{n}$ & $\%$ \\
\hline Only undergraduate medics (UG) & 8 & 9.5 \\
\hline $\begin{array}{l}\text { Both UGs and Postgraduate (PG) } \\
\text { medics }\end{array}$ & 3 & 3.6 \\
\hline UG medics and nursing staff & 1 & 1.2 \\
\hline Only PG medics & 4 & 4.8 \\
\hline PG medics and nursing staff & 1 & 1.2 \\
\hline All & 67 & 79.8 \\
\hline Total & 84 & 100.0 \\
\hline
\end{tabular}

Table 3: Suggestions provided by the respondents.

\begin{tabular}{|ll|}
\hline Suggestions & n (\%) \\
\hline Good experience & $70(83.3 \%)$ \\
\hline Increase number of class & $23(27.4 \%)$ \\
\hline $\begin{array}{l}\text { Increase number of class, nervous } \\
\text { experience }\end{array}$ & $1(1.2 \%)$ \\
\hline Increase number of class, reduce duration & $3(3.6 \%)$ \\
\hline Need for skill demonstration (drug ADM) & $2(2.4 \%)$ \\
\hline Nervous experience, live stream required & $1(1.2 \%)$ \\
\hline Nil & $23(27.4 \%)$ \\
\hline Reduce duration of class & $5(6.0 \%)$ \\
\hline Request for pre/post questionnaire & $1(1.2 \%)$ \\
\hline Study material to be provided & $3(3.6 \%)$ \\
\hline $\begin{array}{l}\text { Topic should be shared for better } \\
\text { understanding }\end{array}$ & $2(2.4 \%)$ \\
\hline Topic should not be shared & $1(1.2 \%)$ \\
\hline Total & $84(100.0 \%)$ \\
\hline
\end{tabular}

Table 4: Deficiencies and corrective measures in the methodology.

\begin{tabular}{|c|c|c|}
\hline Response & Modification & n $(\%)$ \\
\hline $\begin{array}{l}\text { Nervous } \\
\text { experience } \\
\text { as an active } \\
\text { learner }\end{array}$ & $\begin{array}{l}\text { observers to be in another } \\
\text { room and live streaming of } \\
\text { the simulated scenario is } \\
\text { advisable }\end{array}$ & $1(1.2 \%)$ \\
\hline $\begin{array}{l}\text { Pre and post } \\
\text { test } \\
\text { assessments }\end{array}$ & $\begin{array}{l}\text { Evaluation of responses pre } \\
\text { and post test responses to } \\
\text { questionnaire }\end{array}$ & $1(1.2 \%)$ \\
\hline $\begin{array}{l}\text { Topics for } \\
\text { simulation } \\
\text { exercise }\end{array}$ & $\begin{array}{l}\text { No prior sharing of } \\
\text { pharmacology topic. } \\
\text { Exposure to various } \\
\text { scenarios mimicking that } \\
\text { of emergency room }\end{array}$ & $1(1.2 \%)$ \\
\hline
\end{tabular}

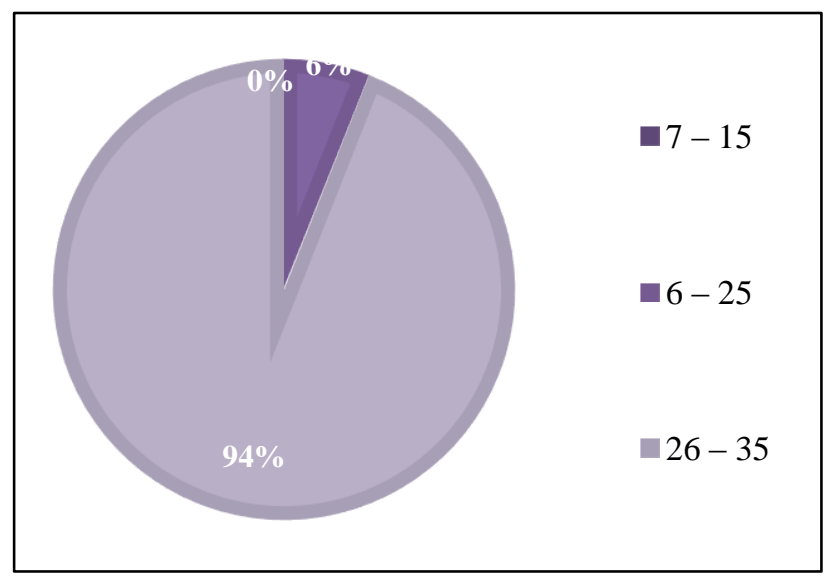

Figure 1: Cumulative score. 


\section{DISCUSSION}

Use of SBL is not limited to simulate only the clinical conditions to familiarise the healthcare professional and enhance procedural skill. Its purpose is being extended to all aspects of the healthcare system to ascertain the safety of patients and enhance the technical skills.

Simulation-based teaching and learning pharmacology is gaining popularity. It is perceived that SBL improves learning and recall ability, broadens perspective compared to lectures. ${ }^{8-9}$

Pharmacology in India is primarily taught using didactics, Case-Based Learning (CBL), Problem Based Learning (PBL) and other methodologies to make the subject interesting and understandable easily. Although these are effective learning tools for medical education, they are not as profound as experiential learning observed in simulation. In simulation-based education, learning is more student' centric and hands-on training. ${ }^{10-11}$ Atrey $\mathrm{M}$ et al, observed that the yield with SBL is good in terms of enhanced retaining capacity $(96.8 \%)$, better scoring and application of theoretical knowledge in the given practical scenario; it was more useful in experimental pharmacology excluding the necessity of animals. ${ }^{12}$ SBL and teaching were more interesting $(96.8 \%)$. Students preferred SBL for their learning in future $(83 \%)$ and perform practical skills/techniques $(63.8 \%)$. Computer skill is necessary for the trainer and students for a better utilization of this mode of teaching and learning. However, Kasturi $\mathrm{R}$ et al ${ }^{13}$ differed in the long term retention and recall of the pharmacology topic studied. ${ }^{13}$

In the present study, authors observed that during SBL scenarios, students learn and unlearn using multiple methods like observing and listening eventually making them understand the Pharmacology better. Around $83 \%$ of students found SBL in pharmacology a good experience. The findings of present study demonstrated that students perceived SBL methodology to be useful to medical, nursing undergraduates, postgraduates and medical professionals. It also helped in retention of topics studied in Pharmacology, enhanced their decision-making skills, improved their interpersonal communication skills among the active learners and observers during scheduled SBL in Pharmacology hence, providing a productive learning environment. Present study findings demonstrated that $2^{\text {nd }}-$ year medical undergraduate students perceived the usefulness of SBL as it supports the development of competency-based clinical skills.

Present study results are similar to the results from Ennen $\mathrm{CS}$ et al, who reported that students gain confidence during simulation scenarios due to improvement in communication and decision-making skills. ${ }^{3}$ In the present study, $92 \%$ of the students felt that SBL enhanced their decision making, communication, and teamwork and skill development. Participants elsewhere thought it was a good opportunity using high fidelity mannequins which 'talks, breaths and blinks' because it made them feel closer to reallife scenarios. ${ }^{14,15}$

This learning helps students to face similar clinical scenarios with more confidence in future. Chakravarthy et al, in 2011 conducted a study where students showed improvement in medical knowledge, confidence and higher understanding of the subject during their emergency rotation. ${ }^{16}$ The results show that Simulation-based education methodology in pharmacology is well received by medical undergraduates and feel that their knowledge of the subject is enhanced through this process.

However, there are few complexities associated with SBL. It may foster artificial than genuine communication skills among students and can promote negative learning. Students are observed to be hypervigilant in the occurrence of an untoward event that may be about to appear. An adequate number of dedicated and exclusive simulator educators are required for this small group teaching methodology. Furthermore, few students felt that more hands-on and skill-based training should be a part of such simulation scenarios as well as more number of classes be included in Pharmacology so that they can learn in a stressfree, safe and non-threatening learning environment.

The simulation techniques cannot demonstrate individual variations exhibited in humans. If not correctly programmed, the objective of imparting correct knowledge will not be achieved. ${ }^{17}$ The learning attitude of the student also influences it. ${ }^{18}$ Other impeding factors include cost, time, infrastructure, difficulties in programming, achieving individual learning objectives. ${ }^{19}$

Although the finding of this study suggests satisfaction with SBL methodology, the study population was small and was limited to only one institution, and hence the results cannot be used entirely as a stereotype.

The population size was small and included students during their second year in MBBS only which makes generalisation difficult. Larger sample size with students from $3^{\text {rd }}, 4^{\text {th }}$-year MBBS and interns can also be used in the future. The challenges reported were few and can be inculcated into future simulation studies.

The data suggests that students perceived that SBL provided them with a better clinical understanding of cases and treatment. The comments were positive and focused on their liking towards this learning methodology. Through changes in the mannequin's parameters, when a right drug or right intervention was followed, they were able to understand the mechanism of a particular drug of action and hence the rationale of using it. The results can be utilized for future training medical graduates and the implementation of simulated activities in our curriculum. It will result in problem-based approach to learning, improve learning and makes learning interesting in the subject. 


\section{CONCLUSION}

SBL is an effective teaching and learning methodology with adequate participant satisfaction. It can be of immense utility as a learning tool with better outcome regarding learning, retention and recall. It will enhance the subject interest in the learner. Including in the curriculum will help the student in the application of theoretical knowledge in practice.

\section{ACKNOWLEDGEMENTS}

Authors would like to acknowledge the support of the management of Fr Muller Medical College in providing the infrastructure and the material for the study. Authors thank to Dr. MS Latha for her writing assistance in editing and proofreading.

Funding: No funding sources

Conflict of interest: None declared

Ethical approval: The study was approved by the Institutional Ethics Committee

\section{REFERENCES}

1. Morgan PJ, Cleave-Hogg D, Desousa S. Applying theory to practice in undergraduate education using high fidelity simulation. Medical Teacher. 2006 Jan 1;28(1):e10-5.

2. Gaba D. Human work environment and simulators. In: Miller RD, editor. In Anaesthesia. 5th Edition. Churchill Livingstone:1999:18-26.

3. Ennen CS, Satin AJ. Training and assessment in obstetrics: the role of simulation. Best Pract Res Clin Obstetr Gynaecol. 2010 Dec 1;24(6):747-58.

4. Gill M, Andersen E, Hilsmann N. Best practices for teaching pharmacology to undergraduate nursing students: A systematic review of the literature. Nurse Educ Today. 2018;74:15-24.

5. Hughes IE. Computer-based learning-an aid to successful teaching of pharmacology?. NaunynSchmiedeberg's Arch Pharmacol. 2002 Jul 1;366(1):77-82.

6. Thompson TL, Bonnel WB. Integration of highfidelity patient simulation in an undergraduate pharmacology course. J Nur Educ. 2008 Nov 1;47(11):518-21.

7. Seropian M, Dillman D, Lasater K, Gavilanes J. Mannequin-based simulation to reinforce pharmacology concepts. Simulation Healthcare. 2007 Dec 1;2(4):218-23.

8. Cooke C, Gormley GJ, Haughey S, Barry J. Tracing the prescription journey: a qualitative evaluation of an interprofessional simulation-based learning activity. Advances Simulation. 2017 Dec;2(1):14.

9. Arcoraci V, Squadrito F, Altavilla D, Bitto A, Minutoli L, Penna O, et al. Medical simulation in pharmacology learning and retention: A comparison study with traditional teaching in undergraduate medical students. Pharmacol Res Perspectives. 2019 Feb;7(1):e00449.

10. Ayed A, Khalaf I. The outcomes of integrating high fidelity simulation in nursing education: an integrative review. Open J Nur. 2018;292-302.

11. Omer T. Nursing Students' Perceptions of Satisfaction and Self-Confidence with Clinical Simulation Experience. J Educ Pract. 2016;7(5):131-8.

12. Atray M, Agrawal A, Atray D. Comparative effectiveness of simulation based teaching versus conventional teaching for undergraduate students of second professional M.B.B.S in experimental pharmacology. Int J Pharm Sci Res. 2017;8:1492-97.

13. Kasturi R, Heimburger G, Nelson E, Phero J, Millard RW. Does human simulator-aided learning improve long-term retention of autonomic pharmacology concepts and facts by year II medical students. Med Sci Educ. 2009;19(3):89-94

14. Founds SA, Zewe G, Scheuer LA. Development of high-fidelity simulated clinical experiences for baccalaureate nursing students. J Professional Nur. 2011 Jan 1;27(1):5-9.

15. Baptista RC, Martins JC, Pereira MF, Mazzo A. Students' satisfaction with simulated clinical experiences: validation of an assessment scale. LatinAm J Enfermagem. 2014 Oct; 22 (5): 709-15.

16. Chakravarthy B, ter Haar E, Bhat SS, McCoy CE, Denmark TK, Lotfipour S. Simulation in medical school education: review for emergency medicine. Western J Emergency Med. 2011 Nov;12(4):461.

17. Weller JM, Nestel D, Marshall SD, Brooks PM. Simulation in clinical teaching and learning. Med J Aust. 2012;196(9):45-8.

18. Datta R, Upadhyay KK, Jaideep CN. Simulation and its role in medical education. Med $\mathrm{J}$ Armed Forces India. 2012 Apr;68(2):167-72.

19. Krishnan DG, Keloth AV, Shaikh U. Pros and cons of simulation in medical education: a review. Int $\mathbf{J}$ Med Health Res. 2017;3(6):84-7.

Cite this article as: Pereira N, Udaykumar P, Sherif L. Simulation based learning methodology in pharmacology: knowledge and perception among second year medical under-graduate students. Int J Basic Clin Pharmacol 2019;8:420-4. 